\title{
Direct Selling Program Strategy Through Online Reporting System Design With "Ipa \& Qfd" Method (Case Study at PT. Global Green Trading)
}

\section{Tukhas Shilul Imaroh and Reza}

Mercu Buana University

\section{Abstract}

This study aims to determine the attributes that become the perceptions and expectations of salespeople and determine the importance of the attributes on the system to be designed, and to know the design of online reporting system in accordance with the wishes of consumers. This research was conducted at PT. Global Green Trading from May until September 2017 with a sample of 30 salespeople

Corresponding Author: Tukhas Shilul Imaroh tukhas.shilul@mercubuana.ac.id

Received: 29 August 2018 Accepted: 18 September 2018 Published: 11 November 2018

Publishing services provided by Knowledge E

(c) Tukhas Shilul Imaroh and Reza. This article is distributed under the terms of the $\mathrm{Cr}$ commons Attribution License, which permits unrestricted use and redistribution provided that the original author and source are credited.

Selection and Peer-review under the responsibility of the ICOI-2018 Conference Committee and data analysis was done using Importance-Performance Analysis and House of Quality matrix that is a form of QFD representation. The results showed that the most important attributes of salesperson in the design of online reporting system of direct selling program is the level of easiness access, the level of easiness in finding information, the availability of information in the presentation of data, the easiness of conducting transactions, the availability of information related to the products offered, and easiness in obtaining the desired information. The result of Importance Performance Analysis shows that every attribute is very important for salespeople so that reporting with this online system can be implemented immediately so that salespeople can be better in doing the activity. The design of online reporting system in accordance with the wishes of the salesperson that is the completeness of the menu, available information required, easiness in the presentation of data, the availability of transaction menu, the visualization of products offered, and easiness of accessing information.

Keywords: designing, online reporting system, direct marketing

\section{Introduction}

Current technological developments have grown rapidly, every time new devices are created to support the easiness of human life, technology infrastructure has become a necessity of human life, one of which is in the world of sales. The rapidly growing technology provides a more attractive sales support tool for the company. One means of support is e-commerce based on android [7]. 
PT. Global Green Trading is one of the companies engaged in the field of promotion. Each division has 6 teams with 4 sales people. Using conventional reporting system using hardcopy/Costumer Data Card (CDC) required hardcopy process periodically so that many expenses incurred.

TABLE 1: Cdc and Cost Requirement PT. Global Green Trading.

\begin{tabular}{l|c|c|c|c|}
$\begin{array}{l}\text { Number of } \\
\text { Team } \\
\text { Member }\end{array}$ & $\begin{array}{l}\text { Number of } \\
\text { Salesgirls }\end{array}$ & $\begin{array}{c}\text { Qty } \\
\text { Cdc/Month }\end{array}$ & Qty Cdc/Year & $\begin{array}{c}\text { Total Production } \\
\text { Cost/Year }\end{array}$ \\
$\begin{array}{l}\text { 6 Team } \\
\text { * 24 persons }\end{array}$ & 36.000 & 432.000 & Rp 151.200.000 \\
\hline *Source: PT. Global Green Trading Area Sunter. &
\end{tabular}

Table 1 shows a waste of costs. Printing costs 1 CDC charged Rp 350/sheet and in 1 day 1 sales personnel need 75 pieces of CDC. Within 1 month the promotion team runs 20 business days, then the company will spend Rp 151.200.000 per year for the entire teams in terms of CDC printing.

TABLE 2: Amount of time needed in inputting at PT. Colony.

\begin{tabular}{l|l|l|l|}
$\begin{array}{l}\text { Number of Team } \\
\text { Member }\end{array}$ & Input Time/Team & Input Time/Day & $\begin{array}{c}\text { Input } \\
\text { Time/Year }\end{array}$ \\
\hline $\begin{array}{l}\text { 6 Team } \\
\text { *Source: PT. Global Green Trading Area Sunter. }\end{array}$ & 120 Minutes & 720 & $\mathbf{1 4 . 4 0 0}$ Minutes \\
\hline
\end{tabular}

Table 2 describes the amount of time required to input each team's CDC within 1 month of work. This amount can be eliminated by the company if the company uses an android based system so there is no need for CDC printing.

This large spending condition and time required can be saved when using android based systems. Research Objectives: (1) To know the attributes that become perceptions and expectations in the design system designed. (2) To determine the importance of attributes that exist within the new system in order to the function and purpose of the new system to remain the same as the conventional reporting system. (3) To know the design of online reporting system in accordance with the wishes of the company.

\section{Literature Review}

E-commerce, according to Jony Wong (2010) understanding of electronic commerce is the purchase, sale and marketing of goods or services through electronic systems, such as radio, television and computer network or internet.

Application Design. Design has essentially been described as a multiple step process in which data representations and program structure, interface characteristics, and 
procedural details are summarized from matters relating to information needs. Soetam Rizky (2011) defines design as a process to define something that will be done using varied techniques and includes a description of the architecture and details of the components also the limitations that will be experienced in the process. According to Roger S. Pressman (2010) defines that the actual design is a software engineering activity intended to make major decisions are often structurally. Based on this understanding that the design is: 1) The process to define something that involves a description of the architecture and components. 2) It's a software engineering activity. 3) Make major decisions that are structurally. 4) It's a liaison between the needs and implementation of Alexandro Yamin (2015) dimensions of application design are as follows:

(1) Display

(2) Easiness in getting information

(3) Completeness of information

(4) Overall application assessment

(5) Recommended product offering.

Direct Selling. A direct selling business is the marketing and selling of products directly to consumers outside of a fixed retail location. According to the Direct Selling Association of Indonesia (APLI) direct selling is a method of selling certain goods and/or services to consumers by way of face-to-face outside fixed retail locations by marketing networks developed by business partners and working on sales commissions, sales bonuses and fair membership fee. Peddling is basically the oldest form of modern direct selling, including sales made through per-party sales plans, demonstrations, and personal contact arrangements and Internet sales.

Importance and Performance Analysis (IPA). is a series of service attributes related to a specific service evaluated based on the importance of each attribute according to the consumer and how the service perceives its performance relative to each attribute. This analysis is used to compare consumer ratings to the importance of service quality (importance) with performance level of service quality (performance). Dimension of service quality used is the quality of service developed by Parasuraman et. al (2009).

Quality Function Deployment (QFD). is a practice for designing processes in response to customer needs. According Sullivan in Ariani (2008) benefits that can be obtained from the application of Quality Function Deployment include:

a. Customer-focused, that is getting input and feedback from customers about the needs and expectations of customers. 
b. Time-efficient, is reducing product development time. The application of QFD develops programs that focus on customer needs and expectations.

c. Time-oriented, QFD uses a group-oriented approach. All decisions are based on consensus and everyone's involvement in discussion and decision-making with brainstorming techniques.

d. Documentation-oriented, QFD uses data, documentation that contains all processes and all customer needs and expectations. This data and documentation is used as information on customer needs and expectations that are constantly fixed from time to time.

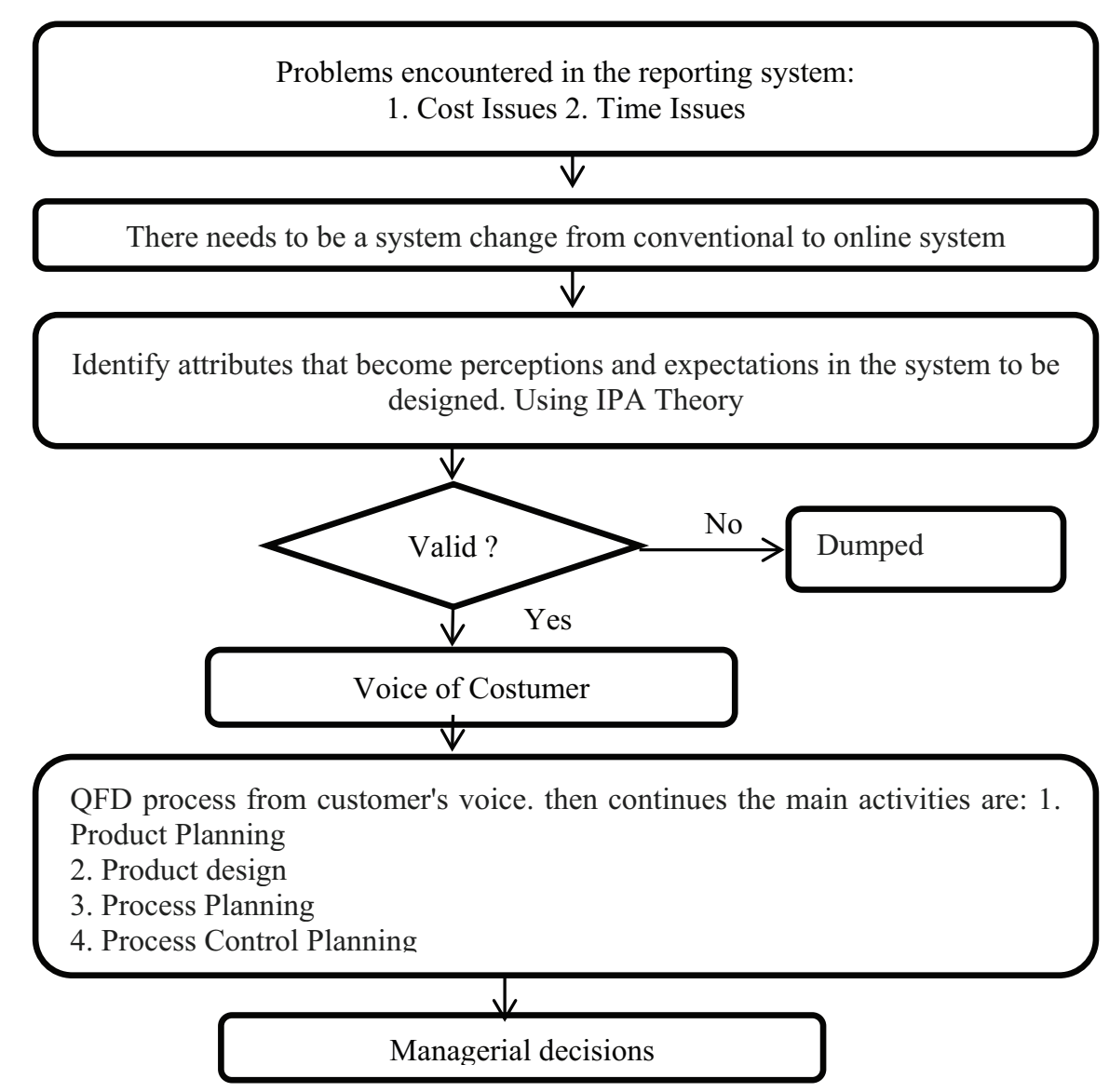

Figure 1: Framework.

\section{Methods}

The method used in this research is as follows: 


\subsection{IPA (Importance and performance analysis)}

IPA is a technique to measure the attributes of interest, done by making ImportancePerformance diagram that will connect the value of importance. The next diagram is divided into four quadrants:

a. Quadrant I indicates that attributes have a high degree of importance, but the performance level of these attributes is low.

b. Quadrant II indicates that attributes have a high degree of importance and the performance level of these attributes is high as well.

c. Quadrant III indicates that attributes have low importance and the performance level of these attributes is low as well.

d. Quadrant IV indicates that attributes have low importance and the performance level of these attributes is high.

\subsection{QFD (Quality function deployment)}

The House of Quality matrix is a representation of QFD, consisting of six main components: Voice of Customer, Technical Response, Relationship Matrix, Planning Matrix, Technical Correlation Matrix, Technical Priorities, Benchmarks, and Targets.

The sample technique used in this study by purposive sampling, as many as 30 (thirty) salespeople of PT. Global Green Trading Area East and North.

\section{Results}

\subsection{Importance performance analysis}

Measurement by using this method is to determine the attributes that made the top priority in making improvements in the form of Cartesian diagram. Obtaining points on the Cartesian diagram, we calculate the average value of the interest rating and the performance of the online direct selling program reporting system design. The results can be seen in Table 3.

$\bar{X}$ and $\bar{Y}=$ The average value of 30 Respondents

Interpretation of the Cartesian diagram can be explained as follows:

(a) Quadrant I (Main Priority). 
TABLE 3: Calculation of average level of interest and performance of online reporting system design direct selling program at PT. Global Green Trading.

\begin{tabular}{|c|c|c|c|c|c|}
\hline Number & Attribute Interest level & $\begin{array}{l}\text { Interest } \\
\text { level }\end{array}$ & $\begin{array}{l}\text { Level of } \\
\text { Performance }\end{array}$ & $\bar{X}$ & $\bar{Y}$ \\
\hline \multicolumn{6}{|l|}{ View } \\
\hline 1 & Accessibility level & 130 & 123 & 4.33 & 4.10 \\
\hline 2 & $\begin{array}{l}\text { Level of ease in finding } \\
\text { information }\end{array}$ & 123 & 120 & 4.10 & 4.00 \\
\hline \multicolumn{6}{|c|}{ Accessibility of the online information system } \\
\hline 3 & $\begin{array}{l}\text { Ease of access by all interested } \\
\text { parties }\end{array}$ & 127 & 117 & 4.23 & 3.90 \\
\hline 4 & $\begin{array}{l}\text { Rate of speed in terms of } \\
\text { presenting information }\end{array}$ & 130 & 118 & 4.33 & 3.93 \\
\hline \multicolumn{6}{|c|}{ Completeness of information } \\
\hline 5 & $\begin{array}{l}\text { Availability of information in the } \\
\text { presentation of data }\end{array}$ & 127 & 124 & 4.23 & 4.13 \\
\hline 6 & $\begin{array}{l}\text { Level of completeness of } \\
\text { information in one menu }\end{array}$ & 125 & 116 & 4.17 & 3.87 \\
\hline \multicolumn{6}{|c|}{ Application ability in performing performance appraisal } \\
\hline 7 & Ease of doing transaction & 127 & 120 & 4.23 & 4.00 \\
\hline 8 & Ratings in sales & 124 & 117 & 4.13 & 3.90 \\
\hline 9 & Speed in terms of performance & 116 & 108 & 3.87 & 3.60 \\
\hline 10 & $\begin{array}{l}\text { Level of accuracy in terms of } \\
\text { assessment }\end{array}$ & 119 & 108 & 3.97 & 3.60 \\
\hline \multicolumn{6}{|c|}{ Recommended product recommendations } \\
\hline 11 & $\begin{array}{l}\text { Availability of information } \\
\text { related to the offered product }\end{array}$ & 130 & 131 & 4.33 & 4.37 \\
\hline 12 & $\begin{array}{l}\text { Ease of obtaining information } \\
\text { desired by consumers }\end{array}$ & 132 & 125 & 4.40 & 4.17 \\
\hline \multicolumn{4}{|c|}{ Average $\bar{X}$ and $\bar{Y}$} & 4.19 & 3.96 \\
\hline
\end{tabular}

This quadrant contains an online reporting system design that is considered important by the sales force but in fact the design of the online reporting system is not in line with the expectations of salespeople. The perception of the design of the online reporting system is lower than the salesperson's expectations level on the design of the online reporting system, so it should be further improved in order to meet the expectations of salespeople. The results of the calculation of questionnaires included in quadrant I is: Level of ease in finding information (No. 2)

(b) Quadrant II (Maintain Achievement).

The design of the online reporting system contained in this quadrant is important and has a good perception. The design of this online reporting system needs to 


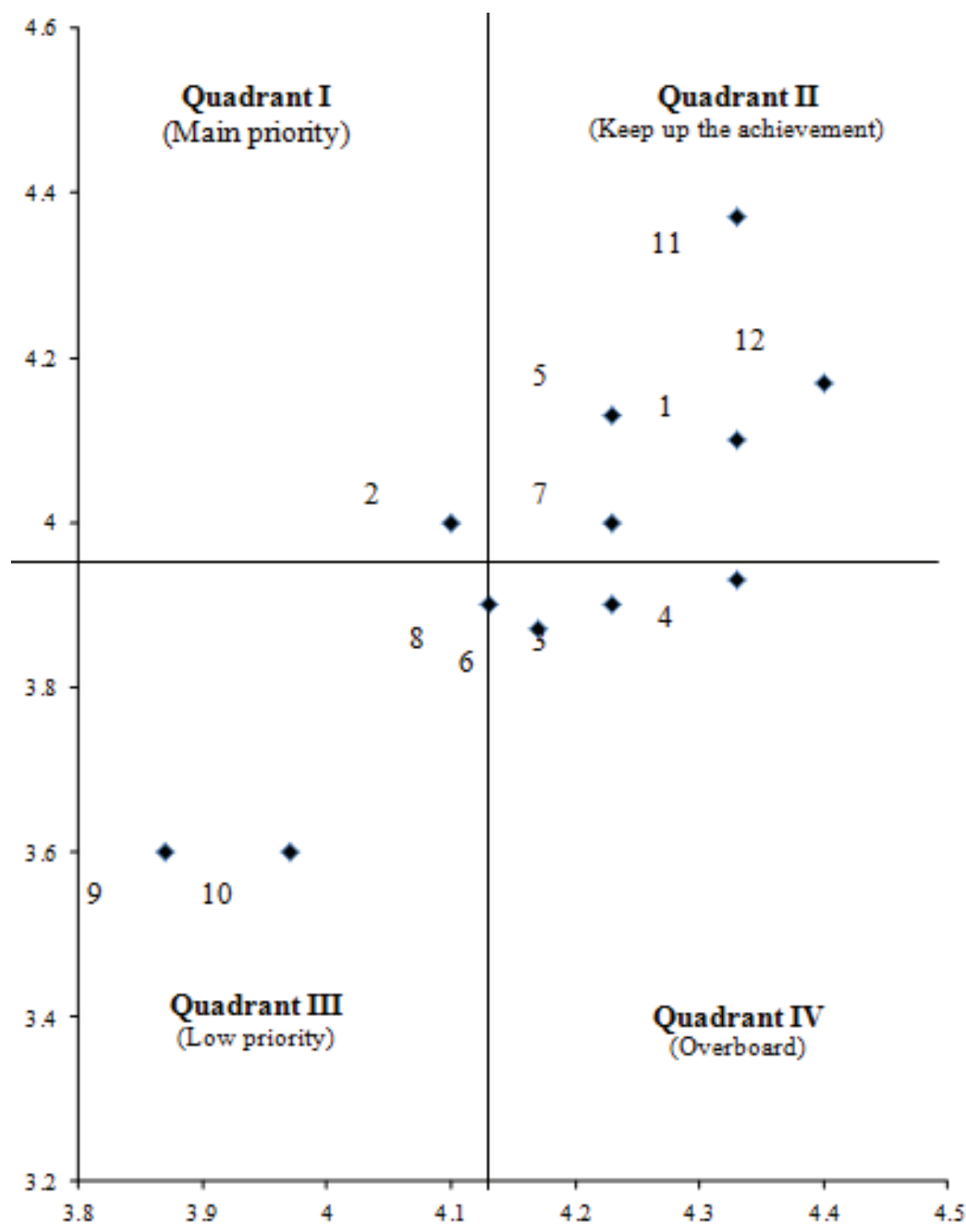

Figure 2: Cartesian diagram dimension designing Online Direct Selling Reporting System.

be maintained. The results of the questionnaire calculations, which are included in quadrant II are:

(1) Accessibility level (No. 1)

(2) Availability of information in the presentation of data (No. 5)

(3) Ease of transaction (No. 7)

(4) Availability of information related to the offered product (No.11)

(5) Ease in obtaining information desired by consumers (No.12)

(c) Quadrant III (Low Priority).

The design of online reporting systems contained in this quadrant is considered less important by the sales force and in fact the perception is not too special. 
Improvements to the design of online reporting systems can be reconsidered because their impact on the perceived benefits of the sales force is very small. The results of the questionnaire calculations, which are included in quadrant III are:

(1) Level of completeness of information in one menu (No. 6)

(2) Rating in sales (No. 8)

(3) Speed in terms of describing performance (No. 9)

(4) The level of accuracy in the assessment (No. 10)

(d) Quadrant IV (Excessive).

This quadrant contains an online reporting system design that is considered less important by the salesperson and felt too much. Improving the design of online reporting systems in this quadrant will lead to wastage. The results of the questionnaire calculations, which are included in quadrant IV are:

(1) Ease of access by all interested parties (No. 3)

(2) Rate of speed in terms of presenting information (No. 4)

\subsection{Quality function deployment analysis}

Figure 3: Matrix HOQ.

The value of weight of interest on the matrix of house quality indicates that the addition of efficiency of information delivery to the consumer has the highest weight. 
Broadly speaking, this $\mathrm{HOQ}$ matrix is an attempt to convert voice of costumer directly to the technical characteristics or technical specifications of a resulting plan. PT. Global Green Trading will try to achieve technical characteristics in accordance with the targets set so that given by the implementing team of online reporting system design direct selling program goes well and the salesperson feel satisfied after feel it directly. In the assessed HOQ Matrix is to know the degree of relationship between (What) and (How) and the end of result is the House of Quality matrix. Based on Figure 3, the needs of the most important salespeople are: the level of ease of access, the level of ease in finding information, the availability of information in the presentation of data, the ease of conducting transactions, as well as the availability of information related products offered and ease in obtaining the desired information.

\section{Discussion}

The results of calculation of the priority of sales people, there are some technical interests that made the top priority in the design of online reporting system direct selling program, namely:

1. Available information required, this condition makes it easier for the salesperson to find information during the transaction, so that the salesperson can present the products offered to the customer with the right and correct and there is no mistake in providing information to the customer.

2. Ease in the presentation of data, can facilitate salespeople in reporting to superiors, thus making the time to be more efficient at the time of reporting.

3. The visualization of products offered, can further facilitate salespeople in obtaining information to be conveyed to the customer without asking questions to superiors, simply by opening the application salesperson can directly present the product offered.

4. Ease in accessing information, can improve the efficiency of salespeople in conveying information to customers so that customers can be directly attracted to the products offered by salespeople.

Priority setting indicates the main priority that must be developed from the technical interest that is based on the needs of salespeople. Based on the calculation of the priority of salespeople, there are some technical interests that made the top priority in the design of online reporting system direct selling program, the completeness of the 
menu, available information required, the ease of presenting the data, the availability of transaction menu, the visualization of products offered, as well as ease in accessing information.

Discussion results between researchers with the company decided to take account the characteristics of other techniques that the completeness of the menu $\&$ the availability of the transaction menu but does not ignore the other technical characteristics required sales people.

\section{Conclusions}

1. The most important attributes of salesperson in the design of online reporting system of direct selling program is the level of ease of access, the level of ease in finding information, the availability of information in the presentation of data, the ease of conducting transactions, and the availability of information related to the products offered and ease in obtaining the desired information. The company added the completeness of the menu for easy transactions.

2. Importance Performance Results Analysis shows that each attribute is very important for salespeople. The company will set up an online system in reporting, so that salespeople can improve the effectiveness, cost efficiency, and time of execution.

3. Designing Online Reporting System that will be prepared by the company in accordance with the needs of sales personnel, that is the completeness of the menu, availability information required, easiness in the presentation of data, the availability of transaction menu, the visualization of products offered, and the easiness of accessing information.

\section{Recommendation}

Required policy to maximize the design of online reporting system direct selling program, especially the field of completeness of the menu on the design of online reporting system direct selling program. And the design of online reporting system, PT. Global Green Trading should provide what is considered important by the salesperson just so as not to cause waste especially in the case of access by all interested parties. 


\section{Acknowledgement}

This research is in accordance with previous research by Arista, et al. entitled 'Customer Satisfaction Analysis Using Attributes Excellent Services by Integrating Importance Performance Analysis (IPA) and Quality Function Deployment (QFD)' (Case study: PT Sang Hyang Seri (Persero) -Malang), which states that from the IPA results can be seen 11 attributes prioritized in the quadrant of one 'Concentrate Here' that is the ability to communicate, employees are responsible for the service, available facilities support, physical appearance of employees neatly, the attitude of employees appreciate, polite to the customer, listening employees, understanding customer needs, employees work according to procedures, respond to customer complaints, employees serve customer needs and employees devote attention to customers.

Based on QFD analysis results, the main priority of improvement recommendations that can be done PT.SHS is the implementation of employee service training.

\section{References}

[1] Anwar, et al. 2013. Service Quality Improvement with Servqual Dimension Model of Tourism and Quality Function Deployment Method. Case study at PT X, Place of Rides Game. Thesis. J @ TI UNDIP, V (1). PP. 41-54. ISSN 1907 - 1434 accessed via http://eprints.undip.ac.id/8153/

[2] Arista, Fatma Khoirunnisa, Nasir Widha Setyanto, \& Oke Oktaviant, 2014, Customer Satisfaction Analysis Using Attributes Excellent Services by Integrating Importance Performance Analysis (IPA) and Quality Function Deployment (QFD), (Case study: PT Sang Hyang Seri (Persero) -Malang), Journal of Rekayasa dan Manajemen Sistem Industri, Brawijaya University

[3] Imbar, Radiant Victor, \& Tirta, Eric, 2007, Analysis, Design, and Implementation of Sales Information System Lubricant Company Case Study PT. Pro Roll International, Journal, Maranatha Christian University

[4] Irmawati, Dewi, 2011, Utilization of E-Commerce in Business World, Journal of ECommerce Utilization in Business World, Department of Information Management State Polytechnic of Sriwijaya

[5] Muluk, Khairul, 2008, Knowledge management: The Key to Successful Innovation of Local Government, Bayumedia Publishing. East Java

[6] Rizky, Soetam, 2011, Basic Concepts of Software Engineering, Jakarta: Achievements. Library. 
[7] Setiawan, 2017, How to Create a Good and True Prototype, Medan: The Media Dilemma

[8] Sukmajati, Anina. 2009. Implementation of E-commerce to Increase Added Value for the Company. http://aninasukmajati.wordpress.com.

[9] Supranto, 2011, Measuring Customer Satisfaction Level to Raise Market Share (Fourth Mold). Jakarta: PT. Rineka Cipta

[10] Yamin, Alexandro, 2015, Design and Creation of E-commerce Website Petra Gaming Store, Journal of Research, Informatics Engineering Program Faculty of Industrial Technology Petra Christian University.

[11] Zeithmal, Parasuraman, 2009, Service Quality: A Conceptual Framework For Understanding e-implication for Future Research and Managerial Practice: Msi Monograph New York. 